\title{
Analysis of Factors in the Formation of Human Resources for the Development of the Digital Economy
}

\author{
Jeanne Kopteva ${ }^{*}$, Roman Krupchatnikov ${ }^{2}$, Irina Tomakova ${ }^{1}$, and Galina Tuboltseva ${ }^{3}$ \\ ${ }^{1}$ Southwest State University, Department of Economics, Management and Audit, 305040 Kursk, 50 \\ years of October, Russian Federation \\ ${ }^{2}$ Kursk State Agricultural Academy named after Professor I.I. Ivanov, Standardization and equipment \\ of processing industries, 30502, Kursk, st. Karl Marx, 70A, Russian Federation \\ ${ }^{3}$ Kursk State Technical School of Technology and Service, 305007 Kursk, st. Tractornaya, 8, Russian \\ Federation
}

\begin{abstract}
At present, the region of the country is trying to actively implement the policy of innovative development, which is clearly reflected in projects such as "Human Resources for the Digital Economy" within the framework of the "Digital Economy in the Russian Federation" program. The Kursk region has sufficient potential for sustainable economic development, which can be achieved by providing highly qualified personnel to build the digital economy. The result of the study is the identification of a number of factors affecting the feasibility of the project "Human Resources for the Digital Economy" of the national program "Digital Economy of the Russian Federation".
\end{abstract}

\section{General formulation of the problem and its connection with important scientific and practical tasks}

In the modern world, economic activity is largely realized through the process of digitalization. The concept of building a digital economy involves the training of appropriate personnel. In this direction, the government of the Russian Federation has developed strategic documents, national programs aimed at creating the necessary conditions for the development of digital platforms and systems in the economy of the country and its regions.

On the official website of the Kursk Region Administration, the passport of the regional project dated 08.16. "Personnel for the digital economy (Kursk region)" (hereinafter referred to as the Project) for the period until December 31, 2024, developed within the framework of the national program "Digital economy of the Russian Federation" $[1 ; 19]$.

In this regard, an urgent task is to identify factors affecting the feasibility of the project "Personnel for the digital economy" of the national program "Digital Economy of the Russian Federation" [1; 12-14].

\footnotetext{
*Corresponding author: koptevvv@mail.ru
} 
Such an analysis of factors will make it possible to fully assess possible problems during the implementation of the project, reduce the influence of negative factors and increase its efficiency.

\section{Analysis of the latest achievements and publications in which the solution of this problem has been started, highlighting the previously unresolved parts of the general problem to which this article is devoted}

The staffing of the digital economy is implemented through the improvement of the education system through the development of relevant competencies.

The relevance of providing the digital economy with personnel with the necessary set of relevant competencies was noted by Dmitry Peskov, Special Representative of the President of the Russian Federation for Digital and Technological Development. Oleg Podolskiy, managing director of the Human Resources Competence Center for the Digital Economy at the University of 2035, and Boris Nuraliev, director of 1C, also pointed out the particular importance of training such specialists [2].

The issue of providing highly qualified personnel to the modern digital economy is highlighted in the works of such authors as L.G. Titarenko. (2020), Shmelkova L.V. (2016), Gokhberg, K.A., Ditkovsky, E.L. (2019), Dyachenko, Bessonova E.A., Mereshchenko O.Yu. (2018) and others [3-11].

In his work "On important aspects of training for the development of the digital economy" Stepanov O.A. considers the main aspects of building a digital infrastructure by training highly qualified personnel [10].

However, the scientific literature does not disclose the factors of the Project implementation, which should be taken into account for the most optimal and efficient implementation of the Project.

\section{Formulation of the goal and setting the tasks of the work}

The purpose of this study is to determine the factors in the formation of human resources for the development of the digital economy in the implementation of the national program "Digital Economy of the Russian Federation".

\section{Presentation of the main research material with full justification of the scientific results obtained, formulation of recommendations}

First of all it is necessary to evaluate the scientific and educational potential of the region, in particular the Kursk region, by analyzing the current state of the number of educational institutions that train personnel for the digital economy (see Figure 1).

In the Kursk region, since 2005, according to statistics, there has been a negative trend in the number of organizations engaged in educational activities of higher and secondary vocational education.

It is also necessary to assess the trend of changes in the number of students in educational programs of various levels of training in educational institutions of higher and secondary vocational education of the Kursk region (Figure 2).

Figure 2 clearly shows the reduction in the number of students enrolled in educational programs of higher and secondary vocational education in the Kursk region. 
The study also analyzed the dynamics of changes in the number of students in educational programs of various levels of training in educational institutions of higher and secondary vocational education of the Kursk region.

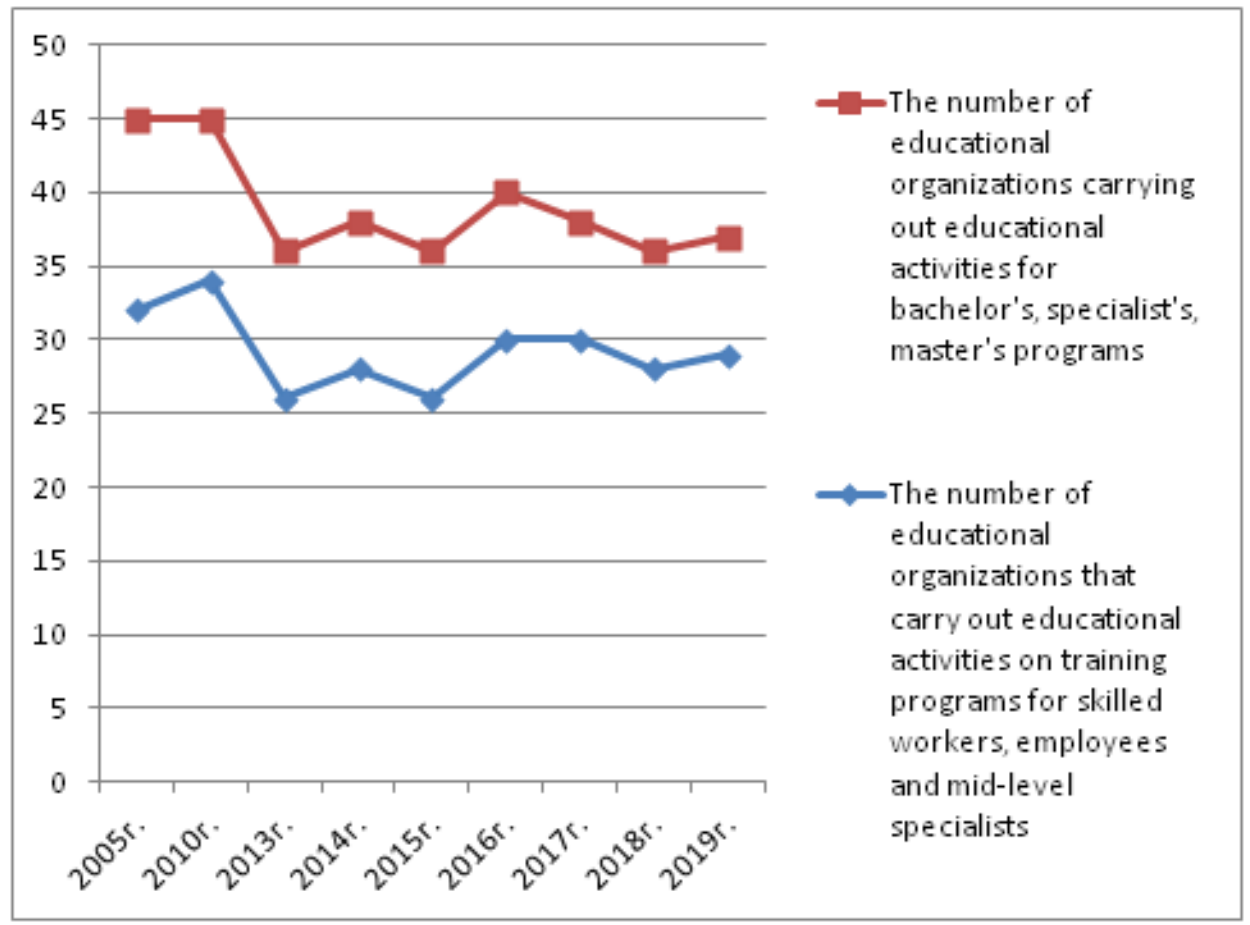

Fig. 1. Dynamics of the number of educational organizations in the Kursk region, carrying out educational activities under the programs of bachelor's, specialist's, master's degrees, programs for the training of skilled workers, employees and mid-level specialists $[15 ; 16]$.

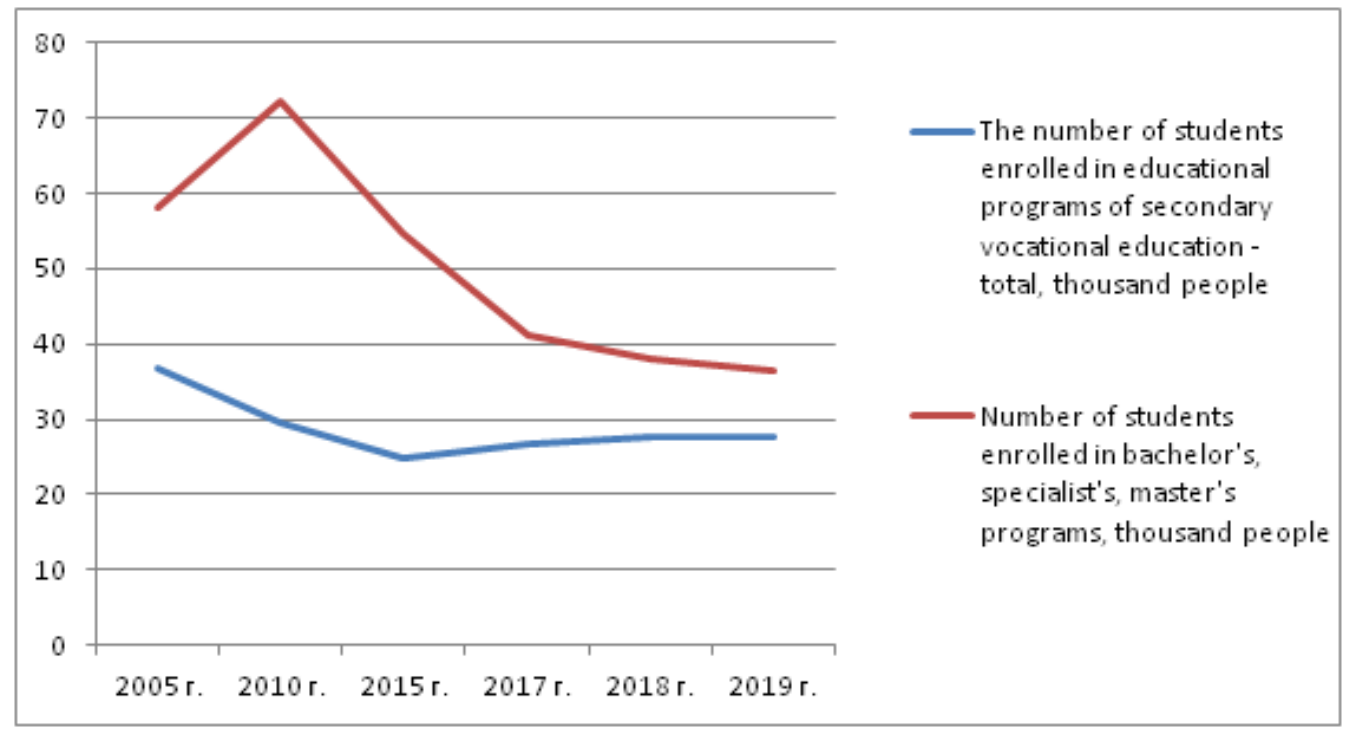

Fig.2. Dynamics of the number of students of organizations carrying out educational activities in the Kursk region $[15 ; 16]$. 
According to regional statistics, the gross enrollment ratio in educational programs of secondary vocational and higher education over the past 15 years has also decreased from $27.3 \%$ to $23.2 \%$ [18].

Of practical interest is the analysis of the dynamics of the teaching staff (PPP) in educational institutions of higher education and scientific organizations that carry out educational activities for undergraduate, specialist and graduate programs and teachers in educational institutions for secondary vocational education programs in the Kursk region.

The number of teachers and masters of educational organizations carrying out educational activities in educational programs of secondary vocational education has a positive trend, and by 2020 increased slightly less than 1.5 times compared to 2017 . But the dynamics of the number of PPP in educational institutions of higher education and scientific organizations that carry out educational activities for bachelor's, specialist's and master's programs has, unfortunately, a negative trend.

The decline in the total number of students in higher education programs and the number of teaching staff is a direct consequence of the decline in the prestige of higher education in the Russian Federation, which has exceeded $30 \%$ on average over the past 10 years. The main reasons for this decline are increased training costs, lack of jobs and low wages.

To eliminate the existing shortage of personnel, the regional project stipulates that, starting in 2019, the approval of the number of applicants admitted to universities to meet the needs of the digital economy in specialists with formed digital competencies.

Within the framework of the study, it is necessary to analyze the dynamics of enrollment of students for full-time bachelor's degree programs, the acquisition of education in which is associated with the formation of two or more key competencies of the digital economy, carried out on the example of the leading university in the region Southwestern State University (SWSU). Thus, the university is recruiting within the framework of the Project in such areas as: 02.03.03 - Mathematical support and administration of information systems; 09.03.01 - Informatics and computer technology; 08.03.01 - Construction; 09.03.02 - Information systems and technologies; 07.03.01 Architecture; 10.03.01 - Information security; 09.03.04-Software Engineering; 10.05.02 Information security of telecommunication systems; 11.03 .02 - Infocommunication technologies and communication systems; 03.38.01 - Economics; 38.03.04-State and Municipal Administration; 38.03.02 - Management, etc.

Thus, there is a positive trend at the university, and by 2021 Southwest State University plans to increase the number of budget places in educational programs, education in which is associated with the formation of two or more key competencies of the digital economy, by $62 \%$ in 2021 compared to 2015 (Table 1 ).

Table 1. Analysis of the dynamics of student recruitment for full-time undergraduate programs at SWSU [17].

\begin{tabular}{|l|l|l|l|l|l|c|c|c|}
\hline $\begin{array}{l}\text { Specialties } \\
\text { (areas of } \\
\text { training) with } \\
\text { relevant } \\
\text { competencies } \\
\text { for the digital } \\
\text { economy }\end{array}$ & $\begin{array}{l}\text { budget } \\
\text { places }\end{array}$ & $\begin{array}{c}\text { out } \\
\text { budget }\end{array}$ & $\begin{array}{l}\text { budget } \\
\text { places }\end{array}$ & $\begin{array}{c}\text { out } \\
\text { budget }\end{array}$ & $\begin{array}{c}\text { budget } \\
\text { places }\end{array}$ & $\begin{array}{c}\text { out } \\
\text { budget }\end{array}$ & $\begin{array}{c}\text { budget } \\
\text { places }\end{array}$ & $\begin{array}{c}\text { out } \\
\text { budget }\end{array}$ \\
\hline Total & 191 & 209 & 283 & 215 & 252 & 217 & 310 & 635 \\
\cline { 2 - 9 } & \multicolumn{2}{|c|}{400} & \multicolumn{2}{|c|}{498} & \multicolumn{2}{c|}{469} & 945 \\
\hline
\end{tabular}


Let us consider the main directions of the implementation of the regional project "Human Resources of the Digital Economy" by the Southwestern State University (Kursk region).

The project "Digital Graduate Portfolio" (P 95.157 - 2019 On the monitoring system of employment and career of university graduates. Order No. 859 dated October 17, 2019) will allow SWSU students to position themselves in the labor market from their best side.

The purpose of the system for monitoring the employment and career of university graduates is a reliable informational reflection of the state of data on the channels of employment and employment of university graduates. To achieve this goal, the following tasks are being solved:

-collection of information and processing of information about employment and career of university graduates;

-analysis and assessment of the demand for graduates of the Southwestern State University;

- providing internal and external users with reliable information on the results of employment of university graduates.

The results of the system for monitoring the employment and career of university graduates are the basis for determining the correspondence of the content, level and quality of training of university graduates to the needs of the labor market.

Another large-scale project that is currently being implemented on the territory of Southwestern State University is "Boiling Point" (P75.170-2019 On the space of the collective labor center "Coworking Southwestern State University". 1198 dated December 30, 2019) ... Boiling Point is a platform for employers, representatives of the business community and the university, as well as students. During the discussions, participants form business ideas, discuss startup ideas and roadmaps for their implementation. The mission of the CC "Boiling Point" of Southwestern State University is to create opportunities for the introduction of new educational formats in order to ensure the competitive professional development of a person in the digital economy. The strategic goal of the Boiling Point CC of Southwestern State University is to develop educational programs and build a trajectory of personal development in order to train personnel capable of creating a competitive business and promoting new knowledge and high-tech technologies to the market.

For the development of entrepreneurial and business competencies of SWSU graduates, the right to use a startup created by a student as a final qualifying work is normatively enshrined - P 02.184-2020 "Graduate qualification work in the form of a business project (start-up)" (Order No. 841). The diploma project can be formalized as a business project (start-up), ready for investment or an operating business. FQP in the form of a business project (startup) is an independent work performed by several students together on the basis of a business project (startup), ready to invest or an operating business, and demonstrates the level of readiness of graduates for independent professional activities. activities.

As part of the project, the university signed agreements on long-term cooperation with 14 universities and research organizations, within the framework of which the network Interuniversity accelerator of technological projects and a venture fund at universities for the development of technological entrepreneurship will operate. be created. Within its framework, an interuniversity network consortium will be created to support promising startups. This will help attract industrial partners and investors [17]. 


\section{Conclusions on this study and prospects for further development of this area}

The Kursk region is trying to actively implement the policy of innovative development of the region, which is clearly reflected by the implemented projects such as "Personnel for the digital economy" within the framework of the program "Digital Economy in the Russian Federation" [1; thirteen]

In this regard, the Council for Strategic Development and Projects (Programs) of the Kursk Region, within the framework of the national program "Digital Economy of the Russian Federation", developed a regional project "Human Resources for the Digital Economy (Kursk Region)". The implementation of this program will create a basis for the development of all sectors of the national economy and a highly efficient renewable human resources for the new digital economy, which will contribute to sustainable long-term economic growth.

The result of the study is the identification of a number of factors in the formation of human resources for the development of the digital economy (Figure 3).

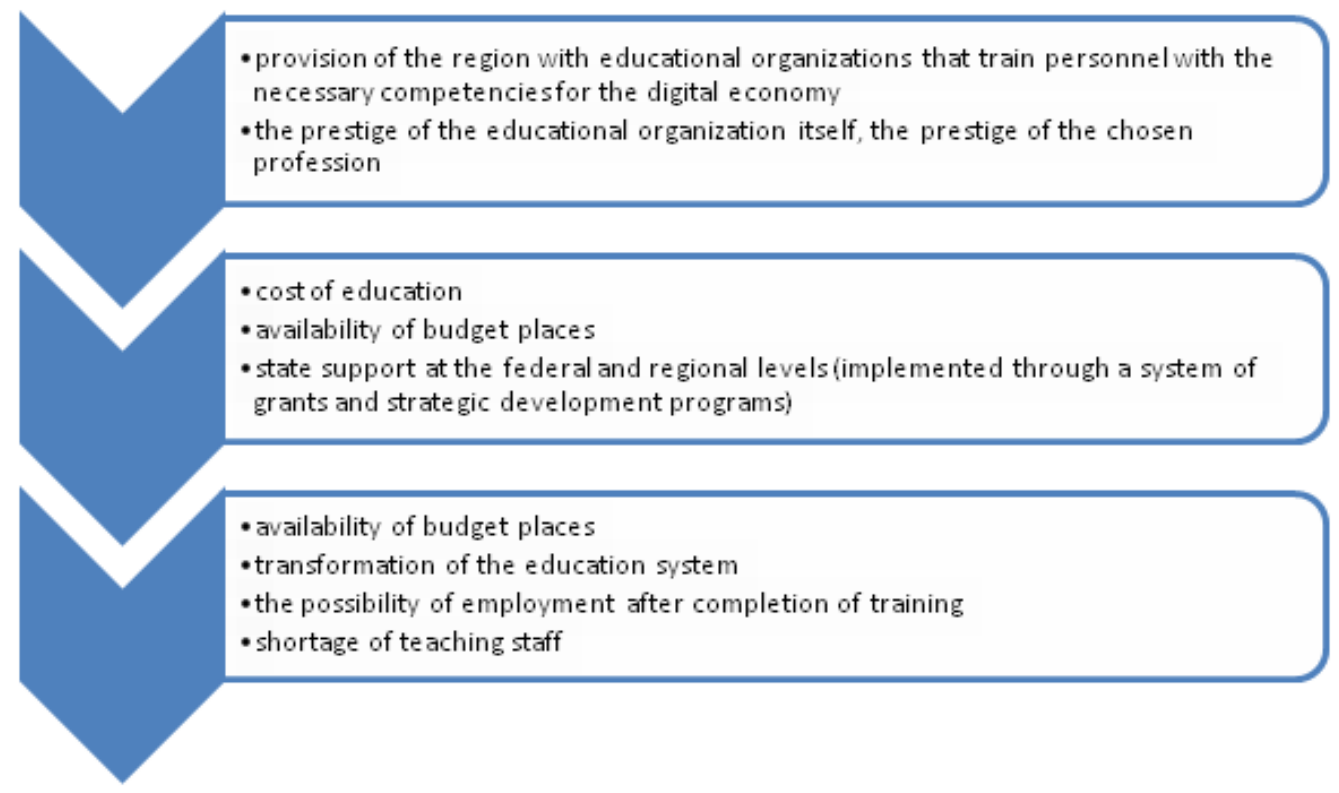

Fig. 3. Factors in the formation of human resources for the development of the digital economy. The main stimulating factor in the development of the digital economy is the comprehensive provision of material, financial, labor and information resources of organizations, including organizations engaged in educational activities.

An important element of the system for improving the quality of training for the digital economy and the development of modern research technologies should be state support at the federal and regional levels of educational organizations that trainpersonnel with a set of key competencies.

For the regions, it is advisable to adapt the experience of leading educational organizations to improve the institutional environment and mechanisms for using their scientific and educational potential in order to train personnel that meet the requirements of the digital economy. In the course of the analysis, it was revealed that at the moment there is a need for a process of modernization and development of the training system with key competencies of the digital economy. 


\section{References}

1.Official site of the Administration of the Kursk region. URL: https://adm.rkursk.ru/index.php?id=110 (date of the application: 10.11.2020).

2. Analytical Center for the Government of the Russian Federation. URL: https://ac.gov.ru/ (date of the application:12.03.2021)

3. Shmelkova L.V. Personnel for the digital economy: a look into the future, Additional professional education in the world, vol. 8 (30). pp.1-4 (2016)

4. Titatenko L.G. Personnel for the digital economy: the effectiveness of university training of young specialists for the labor market, Labor efficiency and the quality of working life in the XXI century. Collection of scientific articles. Edited by R.V. Karapetyan. St. Petersburg. pp. 369-379 (2020)

5. Kopteva Zh.Yu., Afanasyeva L.A., Afanasyev A.A. Optimization of the personnel policy of the enterprise through the introduction of innovative personnel technologies, Modern scientist, vol. 2. pp. 79-82 (2017)

6. Tomakova R.A., Tomakova I.A., Brezhnev A.N. Integrative educational process as a factor in improving the quality of education at the university, News of the South-West State University. Series: Linguistics and Pedagogy. Vol. 8. No.4 (29). pp. 142-155 (2018)

7. Kopteva Z.Yu. Justification of the rational use of natural resource potential as the main factor in the economic development of the region, News of the South-West State University. Series: Economics. Sociology. Management. vol. 2. pp. 57-62 (2013)

8. L.M. Gokhberg, K.A. Ditkovsky, E.L. Dyachenko and others Science indicators: 2019: statistical collection Nat. issled. University "Higher School of Economics". 328 p. (M, NRU HSE, 2019)

9. Bessonova E.A., Mereshchenko O. Yu Methodological approaches to assessing the resource potential of the region, Questions of regional economy. vol. 4 (29). pp. 17-25 (2016)

10. Nigmatullina T.A. Key conditions for training personnel for the digital economy, Bulletin of BIST (Bashkir Institute of Social Technologies). vol. 1 (38). pp. 29-36 (2018)

11. Stepanov O.A. On important aspects of personnel training for the development of the digital economy, Journal of Russian law. vol 11 (263). pp. 106-111 (2018)

12. Laws, codes and legal acts of the Russian Federation. URL: https://legalacts.ru/doc/prikaz-minekonomrazvitija-rossii-ot-24012020-n-41-obutverzhdenii/ .(date of the application 10.11.2020)

13. Order of the Government of the Russian Federation of 08.12.2011 No. 2227-r "On approval of the Strategy for innovative development of the Russian Federation for the period until 2020". URL: http://www.consultant.ru/document (date of the application 11.10.2020)

14. Order of the Ministry of Economic Development of Russia No. 4 dated January 24, 2020 "On Approval of Methods for Calculating Indicators of the Federal Project" Human Resources for the Digital Economy "of the National Program" Digital Economy of the Russian Federation". URL: www.economy.gov.ru (date of the application 10.11.2020)

15. Materials of the website of the Federal State Statistics Service (Rosstat). URL: www.rosstat.gov.ru (date of the application 10.11.2020) 
16. Statistical Yearbook of the Kursk Region. 2020: Statistical collection/ 436 p. (Kurskstat, Kursk, 2020)

17. Official site of South-West State University Specialties of South-West State University URL: https://ee.swsu.ru/specs_2021.php

18. Site material of the Territorial Body of the Federal State Statistics Service for the Kursk Region (Kurskstat). URL: https://kurskstat.gks.ru/ ru (date of the application: 10.11.2020)

19. Herald of the Russian Academy №3. 2019 URL: https://journal.rpamu.ru/Media/journal/archiv/2019/\%D0\%92\%D0\%B5\%D1\%81\%D1\%82\%D0\%BD\%D 0\%B8\%D0\%BA\%20\%E2\%84\%96\%203\%202019.pdf 